\title{
KONCEPCJA SPOŁECZNEJ ODPOWIEDZIALNOŚCI BIZNESU W ZARZĄDZANIU PRZEDSIĘBIORSTWAMI BRANŻY TRANSPORT-SPEDYCJA-LOGISTYKA
}

\begin{abstract}
Z a r y s t r e ś c i: Praca została poświęcona tematyce koncepcji społecznej odpowiedzialności biznesu (ang. CSR - Corporate Social Responsibility) w nawiązaniu do zarządzania przedsiębiorstwami branży Transport-Spedycja-Logistyka (TSL). Autorzy dokonali przeglądu i charakterystyki możliwych form zarządzania w myśl idei CSR, a następnie odnieśli je do organizacji reprezentujących arenę TSL. Ponadto, autorzy przeprowadzili analizę źródeł zastanych (20. i 21. Rankingu Firm TSL Dziennika Gazety Prawnej), na podstawie której starali się określić poziom zaangażowania branży w działania na rzecz CSR.
\end{abstract}

S Ł o w a k 1 u c z o w e: Społeczna odpowiedzialność biznesu, zarządzanie społeczną odpowiedzialnością biznesu, CSR, problemy transportowe, branża TSL.

K l a s y f k a c j a J L: L 21; M14

\section{WSTĘP}

Stosowanie koncepcji społecznej odpowiedzialności biznesu przez przedsiębiorstwa staje się coraz bardziej powszechnie stosowanym trendem biznesowym [Stefańska, 2010, s. 339]. Zgodnie z jego zasadami, organizacje pragną kierować swoją działalnością w taki sposób, aby uwzględniać i wzajemnie równoważyć jej wpływ na środowisko, społeczeństwo oraz gospodarkę [ŚlęzakGładzik, 2013, s.113]. Istotą nie jest jednak wdrożenie pojedynczych praktyk

\footnotetext{
* Adres do korespondencji: Katarzyna Turoń, Politechnika Śląska, Wydział Transportu, Katedra Budowy Pojazdów Samochodowych, ul. Krasińskiego 8, 40-019 Katowice, e-mail: katarzyna.turon@polsl.pl; Piotr Czech, Politechnika Śląska, Wydział Transportu, Katedra Budowy Pojazdów Samochodowych, ul. Krasińskiego 8, 40-019 Katowice, e-mail: piotr.czech@polsl.pl.
} 
w poszczególnych obszarach funkcjonowania przedsiębiorstwa, a przemyślane i całościowe zarządzanie społeczną odpowiedzialnością organizacji.

Odpowiednie zarządzanie aktywnościami na rzecz CSR w branży Transport-Spedycja-Logistyka (TSL) niesie za sobą wiele wyzwań, szczególnie z punktu widzenia szeroko pojętych łańcuchów dostaw [Rudnicka, 2011, s. 399]. Dążenie do ich zrównoważenia (idea zrównoważonych łańcuchów dostaw) to wprowadzanie odpowiednich zmian w strukturach logistycznych przy jednoczesnym pogodzeniu problemów charakterystycznych dla procesów logistycznych, transportowych i spedycyjnych, m.in.:

- zapewnienia odpowiednich standardów ekologiczności,

- eliminowania nieuczciwych praktyk stosowanych w obrocie handlowym (w tym korupcji),

- zapewnienia godnych warunków pracy kierowców (kwestie związane z płacą minimalną),

- zapewnienia bezpiecznych warunków pracy kierowców i pracowników (np. przestrzegania zasad BHP przy załadunkach i rozładunkach),

- zapewnienia odpowiedniego odsetku kobiet na stanowiskach kierowniczych, itd.

Ponadto branża TSL $\mathrm{z}$ uwagi na przemieszczanie ładunków w obszarach transgranicznych, narażona jest na nieustanną współpracę międzykulturową, co stanowi kolejne z wyzwań z punktu widzenia zarządzania międzykulturowego, jak i zarządzania różnorodnością [Golba, Turoń, Czech, 2016, s. 63][Kisperska-Moroń, 2012, s. 19].

Nie należy również zapominać o spełnianiu typowych postulatów transportowych takich jak zapewnienie odpowiedniej jakości, konkurencyjności cenowej, czy bezpieczeństwa przewożonych towarów.

Arena TSL zmaga się zatem z kompendium problemów środowiskowych, ekonomicznych i społecznych (ESG - ang. economical, social, government). Jednym z rozwiązań podanych dylematów może być odpowiednie wdrożenie do obszarów funkcjonowania przedsiębiorstwa koncepcji społecznej odpowiedzialności biznesu.

Celem niniejszej pracy było przedstawienie koncepcji CSR, form zarządzania nią oraz poziomu zaangażowania $\mathrm{w}$ jej działania przedsiębiorstw reprezentujących sektor Transportu-Spedycji-Logistyki.

\section{ZARZĄDZANIE PRZEDSIĘBIORSTWEM A SPOŁECZNA ODPOWIEDZIALNOŚĆ BIZNESU}

Zarządzanie przez społeczną odpowiedzialność stanowi nowy wzorzec postępowania biznesowego [Kisil, 2013, s. 69]. Z punktu widzenia administro- 
wania i kierowania przedsiębiorstwem nie stanowi jednak procesu łatwego do wdrożenia. Dzieje się tak z uwagi na to, że koncepcja CSR jest ideą złożoną, wymagającą systemowego spojrzenia na szeroko pojętą działalność organizacji [Jabłoński, 2013, s. 13].

Rozpatrując zarządzanie pod kątem uwzględnienia koncepcji społecznej odpowiedzialności biznesu wyróżnić można takie formy zarządzania jak:

- zarządzanie uwzględniające uwarunkowania charakterystyczne dla sektora, w którym przedsiębiorstwo funkcjonuje,

- zarządzanie strategiczne organizacji,

- zarządzanie zasobami ludzkimi oraz relacjami przedsiębiorstwa z interesariuszami,

- zarządzanie wartością organizacji,

- zarządzanie ekologicznością organizacji.

Pierwszą z form zarządzania, które ściśle oddziałuje na społeczną odpowiedzialność organizacji jest zarządzanie przedsiębiorstwa z punktu widzenia uwarunkowań branżowych. Każdy sektor gospodarki cechuje się odrębnymi dla niego charakterystycznymi zasadami funkcjonowania. W przypadku branży TSL, kwestie sektorowe nabierają szczególnie dużego znaczenia. Arena TSL to obszar silnie umiędzynarodowiony [Kisperska-Moroń, 2012, s. 19]. Poprzez przepływ dóbr, jak i informacji, pracownicy mają do czynienia ze współpracą na poziomie międzykulturowym, często wymagającym od nich wcześniejszej znajomości specyfiki danej grupy i zapoznania się z charakterystycznymi zwyczajami handlowymi czy sposobem rozwiązywania konfliktów. Aby tego rodzaju współpraca przynosiła korzyści, szczególnie istotne staje się więc odpowiednie zarządzanie różnorodnością $\mathrm{w}$ przedsiębiorstwie. Tworzenie zróżnicowanych zespołów to szansa na realizację polityki społecznej odpowiedzialności biznesu, ale także na poprawę efektywności ich pracy [Golba, Turoń, Czech, 2016, s. 63].

$\mathrm{Z}$ punktu widzenia zarządzania strategicznego, organizacja musi przewartościować swoje zasady postępowania i skupić się na posiadanej wiedzy, kapitale intelektualnym, którym dysponuje i swoich wiodących kompetencjach [Jabłoński, 2013, s. 67]. Wówczas możliwe jest opracowanie strategii postępowania w myśl zasad zrównoważonego rozwoju. Przy jej konstruowaniu istotnym jest, aby odpowiednio określić misję oraz wizję funkcjonowania organizacji, jej szczegółowe zasady postępowania (w tym kodeks zachowań etycznych), standardy, które będą stosowane podczas rozwiązywania konfliktów oraz sposoby nadzorowania i kontrolowania czy organizacja postępuje według wyznaczonych sobie warunków [Gasparski, 2003, s. 69] [Jabłoński, 2013, s. 67].

Zarządzanie zasobami ludzkimi oraz relacjami przedsiębiorstwa $\mathrm{z}$ interesariuszami stanowi kolejną z grup zarządzania z jaką powinna zapoznać się organizacja społecznie odpowiedzialna. Wtedy też, istotnym jest zdanie sobie sprawy z faktu, że pracownicy organizacji stanowią przede wszystkim jej głównych 
interesariuszy [Turoń, 2016, s. 39]. Odpowiednie postępowanie wobec zatrudnionych może zatem przynieść pozytywne skutki w postaci wizerunku przedsiębiorstwa jako uwzględniającego potrzeby i szanującego różnorodność swoich pracowników. Nieodpowiednie zarządzanie wiąże się natomiast z ryzykiem postrzegania organizacji jako niegodnie traktującej swoich interesariuszy, a w efekcie powstania przeświadczenia o nieodpowiedzialności firmy, co w przypadku organizacji z misją społecznej odpowiedzialności jest działaniem niedopuszczalnym.

Kolejną z form zarządzania stosowaną z uwagi na odpowiedzialność organizacji jest zarządzanie jej wartością. Jak podaje A. Jabłoński, autor książki pt. „Modele zrównoważonego biznesu w budowie długoterminowej wartości przedsiębiorstw z uwzględnieniem ich społecznej odpowiedzialności”, można wyznaczyć siedem warunków brzegowych, których celem jest odpowiednie połączenie ze sobą koncepcji CSR z budowaniem wartości organizacji [Paliwoda-Matoliańska, 2014, s. 8]. Do tego typu założeń zalicza się [Jabłoński, 2013, s. 94]:

- przyjęcie, że organizacja ma za zadanie funkcjonować od chwili obecnej do „nieskończoności”,

- generowanie przez organizację zysku i inwestowanie go w tworzenie nowych wartości dla klientów organizacji,

- współpraca z pozostałymi podmiotami, które funkcjonują na rynku, w celu osiągnięcia nowych możliwości do budowania wartości dla firmy,

- bycie otwartym na dokonywanie zmian w produktach i usługach, w celu dążenia do ciągłego rozwoju organizacji,

- prezentowanie postawy społecznie odpowiedzialnej i wykazywanie uczciwości w swoich działaniach biznesowych,

- posiadanie misji, która oprócz generowania zysku przez przedsiębiorstwo skupia się także na tworzeniu dobrych praktyk dla społeczeństwa i środowiska,

- postrzeganie osiągniętego zysku jako nagrody za oferowanie swoim klientom wartości.

Ostatnią z analizowanych form zarządzania jest zarządzanie ekologicznością przedsiębiorstwa. Tego typu sposób prowadzenia organizacji na przestrzeni ostatnich lat zmieniał swój charakter nawiązując do innowacji technologicznych, wdrażania systemów zarządzania środowiskiem, czy tworzeniu się zasad ekologicznej efektywności Z punktu widzenia społecznej odpowiedzialności biznesu, kwestie ekologii silnie wiążą się z zarządzaniem wartością przedsiębiorstwa. Oznacza to, że wszelkie kwestie związane z aspektami CSR mają zostać połączone z procesami zarządzania z uwzględnieniem perspektywy ekologicznej, a całość odnosić się ma do budowania nowej wartości dla interesariuszy (cele, procesy, działania). Taka koncepcja wpisuje się w trendy tzw. „zielonego zarządzania" [Jabłoński, 2013, s. 97-113]. 


\section{SPOŁECZNA ODPOWIEDZIALNOŚĆ BIZNESU W BRANŻY TRANSPORT-SPEDYCJA-LOGISTYKA}

W celu sprawdzenia zaangażowania przedsiębiorstw branży TSL w aktywność na rzecz CSR oraz podejścia do zarządzania społeczną odpowiedzialnością przedsiębiorstw, przeprowadzone zostało badanie polegające na przeglądzie informacji związanych z CSR. Badanie swoim zakresem objęło przedsiębiorstwa sklasyfikowane w 20. i 21. edycji Rankingu Firm TSL Dziennika Gazety Prawnej. Do analizy wybrane zostały organizacje, które osiągnęły największe przychody z działalności opartej na transporcie, spedycji i logistyce w latach 2014 -60 organizacji i $2015-61$ organizacji.

Badane organizacje charakteryzowało zróżnicowane pochodzenie kapitału polskiego jak i zagranicznego. Na podstawie przeprowadzonej analizy można stwierdzić, że spośród analizowanych w latach 2014 i 2015 działań przedsiębiorstw branży TSL, aktywności na rzecz CSR występowały u:

- 25\% wiodących w branży firm w 2014 roku,

- 39\% wiodących w branży firm w 2015 roku.

Wzrost ten wskazuje na zwiększenie zainteresowania tematyką społecznej odpowiedzialności wśród organizacji sektora TSL. Również w przypadku raportowania aktywności na rzecz CSR zauważyć można tendencję wzrostową. Z badania wynika, że raportowania aktywności związanej z CSR podjęło się:

- $11 \%$ wiodących w branży firm w 2014 roku,

- $21 \%$ wiodących w branży firm w 2015 roku.

Szczegółowe dane $\mathrm{z}$ analizy zostały zaprezentowane w tabeli 1.

Tabela 1. Społeczna odpowiedzialność biznesu w branży Transport-Spedycja-Logistyka - zestawienie dla lat 2014 i 2015

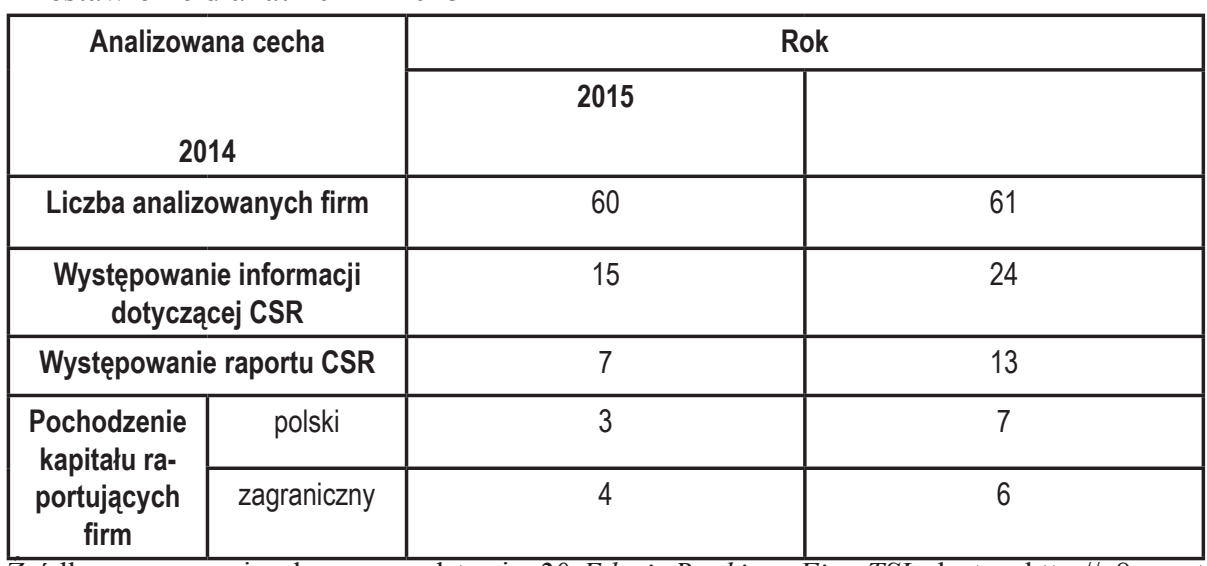

Zródło: opracowanie własne na podstawie: 20. Edycja Rankingu Firm TSL, dostęp: http://g8.gazetaprawna.pl/p/_wspolne/pliki/2229000/2229605-tsl-nowy.pdf z dnia 20.04.2017; 21. Edycja Rankingu Firm TSL., dostęp: http://g5.gazetaprawna.pl/p/_wspolne/pliki/2591000/2591057-dgp-2016-0627-21-edycja-rankingu-firm-tsl.pdf z dnia 20.04.2017 
Kolejnym krokiem badania było dokonanie sprawdzenia sposobu przygotowania przez przedsiębiorstwa raportów oraz wybranego przez nich standardu raportowania. Spośród 13 analizowanych raportów społecznej odpowiedzialności, 9 przygotowanych zostało według wytycznych Global Reporting Initiative - GRI G4 - będącego wiodącym wzorcem raportowania CSR. Oznacza to, że niemal 70\% raportów uwzględnia szczegółowe informacje dotyczące zarządzania w przedsiębiorstwach i aspektów z nim związanych.

W badanych raportach dominują kwestie zarządzania środowiskowego scharakteryzowanego dobrymi praktykami dotyczącymi ekologiczności produktów czy oferowanych usług. Ponadto wiele praktyk skupia się wokół zarządzania zasobami ludzkimi czy szeroko pojętego zarządzania ukierunkowanego na działalność obszarową związaną z TSL z uwzględnieniem w misji przedsiębiorstwa zasad CSR.

\section{PODSUMOWANIE}

Odpowiednie zarządzanie przedsiębiorstwem nie stanowi dla organizacji łatwego zadania. Proces ten wiąże się z dopasowaniem funkcjonowania firmy do warunków brzegowych, które wiążą się z wyznaczeniem odpowiednich celów, spełnieniu wzrastających oczekiwań klientów, nieustannie zwiększającej się konkurencji oraz wszelkich ograniczeń nałożonych odgórnie przez prawo [Lewandowski, 200, s. 13]. Aby jednak organizacja mogła w pełni funkcjonować w otoczeniu rynkowym, istotne jest nie tylko dopasowanie się do warunków brzegowych, ale także do wymagań, które dyktowane są przez trendy otoczenia [Korpus, 2006, s. 39]. Tego typu trendem na przestrzeni ostatnich lat staje się koncepcja społecznej odpowiedzialności biznesu.

Analizując działania w zakresie CSR wiodących na rynku przedsiębiorstw TSL można stwierdzić, że widoczny jest wzrost zainteresowania wdrażaniem koncepcji w organizacjach. Ponadto, w aktywnościach firm można zaważyć występowanie licznych praktyk CSR, będących przemyślanymi działaniami odnoszącymi się bezpośrednio do stosowanych w organizacjach form zarządzania. Praktyki te dotyczą głównie zarządzania ekologicznością oraz zarządzania zasobami ludzkimi. Tego rodzaju działania liderów rynkowych mają szansę na ukształtowanie się wśród mniejszych podmiotów gospodarczych przekonania, że koncepcja CSR to nie tylko trend i pojęcie kojarzone $\mathrm{z}$,public relations”, ale szansa na inwestowanie społecznie odpowiedzialne, łączące w sobie korzyści finansowe przy jednoczesnym respektowaniu czynników ESG [Czerwonka, 2013, s. 45]. 


\title{
LITERATURA
}

Czerwonka M., (2013), Inwestowanie społecznie odpowiedzialne, Wydawnictwo Difin, Warszawa.

Dziennik Gazeta Prawna, (2014), 20. Edycja Rankingu Firm TSL, dostęp: http://g8.gazetaprawna. pl/p/_wspolne/pliki/2229000/2229605-tsl-nowy.pdf z dnia 20.04.2017

Dziennik Gazeta Prawna, (2015), 21. Edycja Rankingu Firm TSL., dostęp: http://g5.gazetaprawna. pl/p/_wspolne/pliki/2591000/2591057-dgp-2016-06-27-21-edycja-rankingu-firm-tsl.pdf z dnia 20.04.2017

Golba D., Turoń K., Czech P., (2016), Różnorodność jako szansa i wyzwanie współczesnych organizacji branży TSL, Scientific Journal of Silesian University of Technology. Series Transport vol.90, Gliwice.

Gasparski W., (2003), Europejskie standardy etyki i społecznej odpowiedzialności biznesu, Wydawnictwo WSPiZ im. Leona Koźmińskiego, Warszawa.

Jabłoński A., (2013), Modele zrównoważonego biznesu w budowie dtugoterminowej wartości przedsiębiorstw z uwzględnieniem ich społecznej odpowiedzialności, Wydawnictwo Difin, Warszawa.

Kisil A., (2013), Zarządzanie przez odpowiedzialność. Podstawa odpowiedzialnego biznesu, Wydawnictwo Difin, Warszawa.

Kisperska-Moroń D., (2012), Transformacja łańcuchów dostaw jako podstawa ewolucji kompetencji menadżerskich, „Gospodarka Materiałowa i Logistyka” nr 6.

Lewandowski J., (2000), Zarządzanie środowiskiem w przedsiębiorstwie, Wydawnictwo Politechniki Łódzkiej, Łódź.

Korpus J., (2006), Społeczna odpowiedzialność przedsiębiorstw w obszarze ksztaltowania środowiska pracy, Wydawnictwo PLACET, Warszawa.

Paliwoda-Matiolańska A., (2014), Corporate Social Responsibility in Poland: is there a place for value creation? [w:] Reichel J. (red), CSR Trends. Beyond Business as Usual, Centrum Strategii i Rozwoju Impact (CSR Impact), Łódź.

Rudnicka A., (2011), Zrównoważony rozwój w łańcuchach dostaw, Acta Universitatis Lodzienzis. Folia Oeconomica 261, Łódź.

Stefańska M., (2010), Koncepcja społecznej odpowiedzialności biznesu w handlu detalicznym, Zeszyty Naukowe Uniwersytetu Ekonomicznego w Poznaniu zeszyt 135, Poznań.

Ślęzak-Gładzik I., (2013), Corporate Social Responsibility (CSR) jako koncepcja porzadkujaca relacje między biznesem a społeczeństwem, 'Modern Management Review' vol. XVIII, $20(2 / 2013)$.

Turoń K., (2016), Corporate Social Responsibility to employees: The best labour practices in transport and logistics companies, 'Journal of Corporate Responsibility and Leadership', vol. 3 , iss. 1 .

\section{CORPORATE SOCIAL RESPONSIBILITY CONCEPTION IN MANAGEMENT OF TRANSPORT-SHIPPING-LOGISTICS AREA}

\begin{abstract}
The work was dedicated to Corporate Social Responsibility (CSR) conception in relations to the management of Transport-Shipping-Logistics area. The authors reviewed and characterized possible forms of the management in the terms of CSR and then referred them to organizations representing the TSL area. In addition, authors analyzed the reports (the $20^{\text {th }}$ and $21^{\text {st }}$ Ranking of the TSL enterprises, published by the Gazeta Prawna Journal), to o determine the level of industry involvement in the Corporate Social Responsibility good practices and activities.
\end{abstract}

Keywords: Corporate Social Responsibility, corporate social responsibility management, CSR, transport problems, TSL area. 
